\title{
Customary Norms, General Principles of International Environmental Law, and Assisted Migration as a Tool for Biodiversity Adaptation to Climate Change
}

\author{
Maksim Lavrik ${ }^{1}$ (D)
}

Accepted: 3 January 2022 / Published online: 24 January 2022

(c) The Author(s), under exclusive licence to Springer Nature Switzerland AG 2022

\begin{abstract}
Assisted migration (AM) is a translocation of the representatives of species to areas outside their natural habitats as a response to climate change. This article seeks to identify how customary norms and general principles of international environmental law could guide the development of regulation of AM maximizing the benefits of using AM and minimizing AM-related risks. Among the customary norms and principles of international environmental law discussed in the article and relevant to the regulation of AM are the permanent sovereignty over natural resources, the principle of cooperation, the no-harm rule, the precautionary principle, the principles of prevention, due diligence, and obligation to conduct environmental impact assessment (EIA), the principles of integration and intergenerational equity, common but differentiated responsibilities, and the polluter pays principle, the principles of nonregression, progression, resilience, in dubio pro natura, the principle of ecological proportionality, and the principle of access to information, public participation, and access to justice in environmental matters (principle of good governance, environmental democracy).
\end{abstract}

Keywords Assisted migration · Assisted colonization · Customary norms · General principles of international environmental law $\cdot$ Biodiversity law $\cdot$ Climate change adaptation law

\section{Introduction}

Anthropogenic climate change, including increasing temperatures, rising sea levels, and ocean acidification, force animals and plants to move in search of new and more suitable habitats (see, e.g., Cannone and Pignatti 2014, pp. 201-214). However,

Maksim Lavrik

max-lavrik@yandex.ru

1 Wuhan University, School of Law, Research Institute of Environmental Law, Wuhan,

People's Republic of China 
sometimes the speed of change in the climate in a particular region is faster than the speed of the natural movement of some species or their ability to adapt to the changing climate (Hällfors et al. 2018, pp. 301-305; Hällfors et al. 2014). Against this backdrop, a complex set of measures is required to enable various species to adapt to climate change including assisted migration (AM) - a translocation of the representatives of species to areas outside, and sometimes far beyond, their natural habitats (see, e.g., Hällfors et al. 2018; Camacho 2010, pp. 171-256; Kabaz-Gomez 2012, pp. 111-150; Lopez 2015, pp. 157-190; McCormack 2018, pp. 323-346).

International law does not provide an official definition of AM. One of the most comprehensive doctrinal definitions of AM is "safeguarding biological diversity through the translocation of representatives of a species or population harmed by climate change to an area outside the indigenous range of that unit where it would be predicted to move as climate changes, were it not for anthropogenic dispersal barriers or lack of time" (Hällfors et al. 2014).

$\mathrm{AM}$ is a controversial tool and combines a variety of factors to consider when implementing. Such factors include both ecological and social challenges. For example, AM means that species are translocating to the areas that will be suitable for them in the future but, probably, worse for them at the moment of translocation in comparison with their existing ranges (see, e.g., Zihaohan Sang et al. 2021). Also, the public can support or oppose such projects. Opposition can emerge, for example, not because of the translocation per se but because it is a movement beyond the native ranges of the species (Peterson St-Laurent et al. 2018). Literature on AM focuses, for example, on such issues as appropriate identification of situations when AM is beneficial for the species, what variables to consider in the decision-making, and how to facilitate public engagement and use different forms of knowledge on AM (see, e.g., Hällfors et al. 2017; Park and Talbot 2018; Hagerman and Kozak 2021).

This article seeks to identify how customary norms and general principles of international environmental law could guide the development of regulation of AM maximizing the benefits of using AM and minimizing AM-related risks. The structure of the article is as follows. The next section on preliminary observations identifies relevant customary norms and general principles of international environmental law, both existing and emerging ones. Additionally, it articulates what principles are incorporated in the relevant treaties and highlights that clear-cut categorization of customary norms and general principles is not always possible. The third section focuses on principles that would maximize the benefits of AM. The fourth section analyzes principles that would minimize the risks related to AM. The fifth section focuses on other relevant principles and norms. The sixth section provides concluding comments.

Often the same principle, such as the precautionary principle, can serve both for maximizing the benefits and for minimizing the risks related to AM; that is why, both sections three and four concern the relevant provisions of the principle and its interpretations. Also, this article does not separate the discussion on the relevant customary norms from the discussion on the relevant principles. For example, the no-harm rule and the obligation to conduct environmental impact assessment (EIA) are closely related to the principle of prevention; that is why, section four assesses 
them together in the context of minimizing the potential risks related to AM. Moreover, the principle of prevention and some other principles have a status of customary norms (UN Secretary-General 2018, para 11). The next section provides necessary comments regarding this matter where it is relevant.

\section{Preliminary Observations on the Relevant Customary Norms and General Principles of International Environmental Law}

Unlike national law, international law does not have a clear articulation of what constitutes its sources (Wolfrum 2011). However, the statutes of the international courts and tribunals mention what sources of law they use in resolving the disputes under their jurisdiction (ibid). Thus, according to Art 38 (1) of the Statute of the International Court of Justice (ICJ), the ICJ shall apply international conventions; international custom, as evidence of a general practice accepted as law; the general principles of law recognized by civilized nations; and judicial decisions and the teachings of the most highly qualified publicists of the various nations, as subsidiary means for the determination of rules of law.

In a situation of lack of substantial norms in the treaties, customary norms and general principles of law could guide the regulation and its development. For the recognition of a rule as a customary international law, two criteria are required: state practice and opinion juris, which is the belief that certain conduct is required or permitted under international law (see, e.g., Wolfrum 2011). As it was mentioned previously, some principles such as the principle of prevention have a status of customary international law. Another example of a customary norm is that EIA is required in respect of activities or projects which may cause considerable transboundary environmental effects (Epiney 2009, para 47). However, usually, the categorization of principles and rules as customary norms is debatable. Thus, the status of the noharm rule as a customary norm or general principle in the meaning of the Art 38 (1) ICJ Statute is not well-established (Brunnée 2010, para 16). That is because some observers express their doubts concerning a lack of clear state practice and opinion juris about the no-harm rule (ibid). Some principles, rules, and their elements are in the process towards recognition of their status as customary norms or general principles in a meaning of Art 38 (1) ICJ Statute. Thus, the concept of good governance has not crystallized into customary international law (Brown Weiss and Sornarajah 2013, para 82). Nevertheless, its elements such as transparency, accountability, and rule of law are in a process of doing so.

General principles of international environmental law are the basic ideas of that field of law; they are general in nature, applicable to all relevant actors, and environmental protection around the world (Sands et al. 2012, p. 187). Some of them are enshrined in the multilateral environmental agreements, and in this case, they obtain clear meaning for the specific international environmental regime. However, even if a treaty does not explicitly recognize a principle in its text, the principle still can play a role in the interpretation and development of the treaty (UN Secretary-General 2018, para 9). General environmental principles also can supplement specific rules and express gap-filling functions (ibid, para 10). 
Among the customary norms, existing principles of environmental law, and their components relevant to environmental law and the regulation of AM, specifically, are the permanent sovereignty over natural resources (see Schrijver 2008; Backman 2019; Mancilla 2016), the principle of cooperation (see Wolfrum, 2010; Sinaga 2013; Janusz-Pawletta and Gubaidullina 2015), the no-harm rule (sic utere tuo ut alienum non laedas, see Brunnée 2010; McIntyre 2020; Tanzi 2020), the precautionary principle (see Schröder 2014; Sands et al. 2012, pp. 217-227; de Sadeleer 2020, pp. 135-361; O'Riordan and Cameron 2013; Steel 2015; Cooney and Dickson 2012), the principle of prevention (see UN Secretary-General 2018, para 11; Duvic-Paoli 2018; Yotova 2016), due diligence (see Koivurova 2010; Kulesza 2016; Malaihollo 2021) and obligation to conduct EIA (see Epiney 2009; Wood 2013; Glasson et al. 2012), sustainable development including integration and intergenerational equity (see Beyerlin 2013; Emas 2015; Barral and Dupuy 2015), common but differentiated responsibilities (see Hey 2011; Honkonen 2015; Vanderheiden 2014), and polluter pays principle (see Boyle 2009; de Sadeleer 2014; Munir 2013). Also, further development of regulation on AM needs consideration of the principle of good faith (bona fide), the principle of solidarity, and a concept of common heritage of mankind (see Campanelli 2011; Kotzur 2009; Wolfrum, 2009). Some principles are outside the scope of the article. For example, the principle of rectification at source, which mainly applies to a shipment of waste and does not have wide recognition outside the European Union (about the evolution of this and other principles see, for example, Milligan and Macrory, 2015, pp. 23-37).

The extent to which these principles and norms can influence the development of regulation of AM varies. Some of them, such as the precautionary principle, deal with more specific issues. For example, this principle can guide how risks and uncertainties related to translocations can be integrated into the regulation. Other principles and norms, for example, the principle of cooperation, can provide a general regulatory framework or, if incorporated in the relevant treaties, specify general concepts to the climate, biodiversity, or other international legal regimes.

Such principles as the principle of permanent sovereignty over natural resources, the principle of cooperation, and the no-harm rule are critical as starting points in the regulation. Emerging from the concept of sovereignty, in the post-World War II era, the permanent sovereignty over natural resources reassured the aspiration of developing countries (Schrijver 2008). It was also used for the extension of jurisdictions, for example, to a continental shelf (ibid). The permanent sovereignty over natural resources covers biological diversity. However, sustainable use of natural resources and the no-harm rule require the cooperation of sovereign nations. Cooperation is critical for preventing environmental degradation (UN Secretary-General 2018, para 17). Moreover, for AM which can transcend the borders, coordinated policies are needed (Brodie et al. 2021, pp. 456-458). It is worth noting that an obligation to cooperate in the form of notification in case of emergency is already a customary norm, less recognition is received by the duty of assistance in such cases, and a variety of legal instruments recognize specific transboundary cooperation (UN Secretary-General 2018, para 17).

The United Nations Framework Convention on Climate Change (UNFCCC) recognizes such principles as the no-harm rule and the principle of prevention (Art 2), 
the precautionary principle (Art 3 (3)), common but differentiated responsibilities (Art 3 (1)), sustainable development (Art 3 (4)), cooperation (Art 3 (3), 3 (5)), and intergenerational equity (Art 3 (1), see Peeters 2015, pp. 509-524). The Convention on Biological Diversity (CBD) articulates sovereign rights of states to exploit their natural resources pursuant to their own environmental policies (Art 3), cooperation ("as far as possible and as appropriate", Art 5), sustainable development (Art 1, 2, 6), the no-harm rule (Art 3), and obligation to conduct an environmental impact assessment (Art 14 (1)(a), see Koester 2015, pp. 538-554). The following sections of the article will address them.

The determination of the principles as well-established or emerging is not clear, and other views on their content and status in the international law than expressed in this article are possible (on the formation of principles and customary norms of international environmental law and their legal validity, see, e.g., Bodansky 2010, pp. 191-204). Thus, some states accept the precautionary principles as the principles of international environmental law, while others reject this position and prefer to name it as the precautionary approach denying its status as a principle of international environmental law (see, e.g., Sands et al. 2012).

Even though some of the ideas are not yet achieved a status of principles of environmental law, they are becoming influential factors both in the development of law and in academia regionally and globally. Among them are the principles of nonregression (UN Secretary-General 2018, para 22), progression (ibid), resilience (see Robinson 2014, p. 19), in dubio pro natura (see The Supreme Court of Pakistan 2021; Conference of Judges and Prosecutors 2018), the principle of ecological proportionality (see Winter 2018, pp. 234-250), and the principle of good governance (environmental democracy) including the principle of access to information, public participation, and access to justice in environmental matters (see UN Secretary-General 2018, para 14, 15; about the emerging principles see also Le Club Des Juristes 2017; IUCN World Commission on Environmental Law 2016; Kravchenko et al. 2012, pp. 58-60; Prieur 2018, pp. 215-259). Also, further development of the right to a clean and healthy environment could integrate AM-related issues as far as AM can be used for maintaining ecosystem services and resilience of ecosystems (on the right to clean and healthy environment see UN Secretary-General 2018, para 18, 19; Boer 2015, pp. 52-75). The regulation of AM can be framed under the ecosystem approach which is claimed to be a principle of international environmental law (Morgera 2015, pp. 70-80).

Table 1 illustrates the relevance of the existing and emerging general principles of international environmental law to AM issues. The following sections of the article provide detailed commentary. Table 1 is a simplification that is provided for the better visualization and structuration of the issues. However, in a real regulation, a more nuanced understanding of the principles and their correlation with the norms on AM is needed. The general idea for distinguishing the principles into the groups is that some principles are more favorable to AM than others; thus, they can be used for maximizing the benefits from using this tool. The provisions of other principles better fit the conservation of the status quo not the application of the AM; thus, they can be used for better understanding and prevention of the negative impacts from $\mathrm{AM}$ projects. However, some principles are relevant to the regulation on AM but 


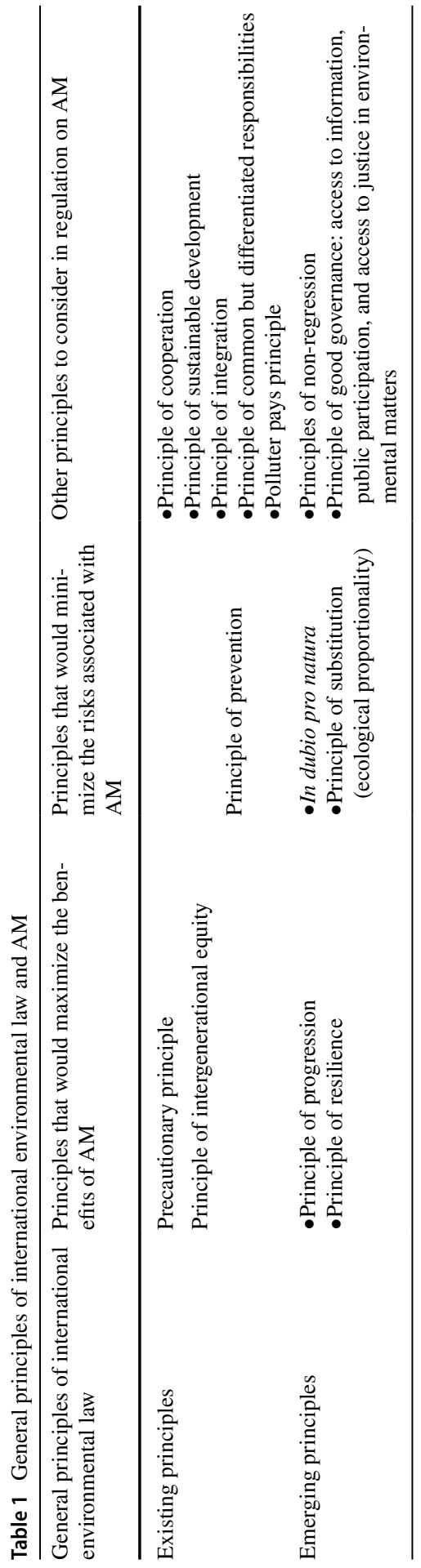


cannot be classified as supportive or opposing to this tool; thus, they will be discussed both as the principles which could maximize the benefits and the principles which could minimize the risks related to AM, e.g., the precautionary principle or the principle of intergenerational equity. Due to the limited volume of the article, it does not provide a detailed assessment of all principles and norms mentioned in this section focusing on those aspects that are the most relevant to the regulation of AM.

\section{Principles that Would Maximize the Benefits of Assisted Migration}

This section argues that environmental law and policy can maximize the benefits from using AM by following the precautionary principle, the principle of intergenerational equity, and the principles of progression and resilience. It points out that the lack of full scientific certainty on the conditions of species under the changing climate cannot be used as a justification for not using AM (the precautionary principle). Also, the next generations should have an opportunity to enjoy the same level of biodiversity as the current generation has (the principle of intergenerational equity), the regulation should integrate the most progressive conservation tools (the principle of progression), and use such tools for maintaining the resilience of the ecosystems and human communities (the principle of resilience).

\subsection{The Precautionary Principle}

AM is closely related to the issues of scientific uncertainties. Science can identify risks for the specific species to become endangered or even extinct due to climatic stressors. However, the prediction of all scenarios of the reaction of ecosystems to a changing climate is highly problematic. Moreover, AM itself is a risky activity that involves the possibility of different types of threats for the recipient sites. Against this backdrop, AM should be guided by a principle that deals with decision-making in a situation of incomplete responses of the science to the questions related to a problem.

The precautionary principle is a general principle of international environmental law that sheds light on desirable behavior in situations of scientific uncertainties (see Sands et al. 2012, pp. 217-227; de Sadeleer 2020, pp. 135-361). Bodansky (2010, p. 201) claims that states and other entities follow the principle not because it is rooted in a specific document that binds them but because they believe that it is the right approach in a situation of scientific uncertainties. Tomasovic (2018, p. 121) highlights that the principle incorporates simple wisdom that we should favor precautionary measures as a principle.

The written form of the principle in law and policy documents helps to clarify what exactly it requires. Rio Declaration articulates the precautionary principle in its Principle 15 (UN Conference on Environment and Development 1992). According to the Declaration, the lack of full scientific certainty is not a reason to postpone measures for environmental protection. Principle 15 also highlights some details for this rule: (1) states shall widely apply the precautionary approach, (2) the 
consideration of capabilities of states is the necessary part of the application of the approach, (3) the prerequisite for the implementation of the principle is the threat of serious or irreversible damage, and (4) the measures in application of the approach should be cost-effective.

The precautionary approach in the interpretation of the Rio Declaration can justify AM. If there is a risk for species to become endangered or extinct due to climatic stressors, the lack of scientific certainty cannot be used as a reason to postpone the AM project. Moreover, Principle 15 encourages states to use the precautionary approach widely; that is why, states should use AM to protect their biodiversity from the negative impacts of climate change.

However, the following is also true if one applies Principle 15 to the AM issues. First, the application of the precautionary approach according to the capabilities of states means, on the one hand, that if a state does not have capabilities to conduct AM project no one can force it to do so. On the other hand, that also means that biodiversity in developed countries has more chances to be saved by using AM than biodiversity in developing countries which probably do not have capacities for the proper implementation and long-term monitoring of such projects.

Second, not every negative consequence for the environment can justify action in a situation of lack of full scientific certainty. The threat of serious or irreversible damage is the necessary condition for the application of the principle. Thus, the risk of extinction of species is a solid justification as it is a risk of irreversible damage to biodiversity. However, it is not obvious how to evaluate the risk if it is not irreversible. The seriousness of risk is a value concept that depends on what kind of risk one considers: the risk for species, for ecosystems, or for states and local communities that depend on the species at risk.

Third, the necessity for the measures to be cost-effective has the following repercussion. Even if decision-makers conclude that risk is serious and irreversible, and $\mathrm{AM}$ can be a tool that protects the environment from such negative consequences, it still can be not implemented if the cost-effectiveness has not been proved.

The relevant treaties incorporate the precautionary principle. Article 3 (3) of the UNFCCC recognizes the precautionary principle as guidance both for mitigation and adaptation. The preamble to the CBD incorporates the precautionary principle. While other documents mention the "threat of serious or irreversible damage", the CBD is more specific. According to the Convention, the hypothesis for using the precautionary principle is "a threat of significant reduction or loss of biological diversity".

The Convention requires to act to minimize or avoid such a threat. Thus, under the $\mathrm{CBD}$, stakeholders can conduct AM projects not only to prevent the extinction of species but also to minimize the threat of significant reduction of biodiversity. However, the term "significant" is a value concept that requires evaluation on a case-by-case basis.

Some policy documents on AM recognize the critical role of the precautionary principle. Thus, the NSW Translocation Operational Policy points out that this principle is an appropriate way to consider proposals for AM until a better understanding of the risks and consequences (Office of Environment and Heritage (NSW Government) (2019), p. 24). 


\subsection{The Principle of Intergenerational Equity}

The next principle the application of which can justify using AM and thus maximize the benefits thereof is the principle of intergenerational equity. Sometimes this principle is treated as part of the principle of sustainable development (Sands et al. 2012, pp. 206-217). The UNEP (p. 26) defines the principle of intergenerational equity as one side of equity in societies. Thus, the equity includes both intergenerational equity (right of future generation to enjoy the same level of benefits as the current generation does) and intragenerational equity (right of all people within the current generation to fair access the existing resources, ibid).

The necessity to consider not only short-term interests but also long-term goals and risks is critical. In satisfying its needs, the present generation should not diminish their life expectancies in the long run as well as the needs of the future generations. The idea that people who live on the earth are not the owners of its resources, but trustees is common for different cultures, religious views, and legal approaches (in Roman law, in public trust doctrine, in the concept of erga omnes obligations, see Michallet 2018, pp. 150-160; Glennon 1990, pp. 1-43). Within academia, the concept of intergenerational equity has received a new impulse in the 1980s stemming from the seminal works of Brown Weiss (see, e.g., Brown Weiss 1992).

The preamble of the UNFCCC mentions the protection of global climate for present and future generations. The CBD in its preamble also recognizes the conservation and sustainable use of biodiversity for present and future generations as its guiding idea. Moreover, the necessity to protect the life and private life of people from the genuine threat of climate change, in the long run, is accepted by a court's ruling against inappropriate policy measures (in the famous Urgenda case, see, e.g., The Supreme Court of the Netherlands, 2019, para 5.2.3, 5.6.2).

The principle of intergenerational equity requires the present generation to transmit to future generations the same opportunity to enjoy biological diversity as the present generation itself has. However, this statement raises a host of theoretical puzzles (on definitional quandary and a lack of legal instruments on the protection of the interests of future generations, see Abate 2019, pp. 43-96). They are rooted in our inability to predict the values and choices of future generations (see Michallet 2018, pp. 150-160). Would they prefer to prevent the extinction of concreate species or to conserve the recipient communities without the introduction of new species? What species would they prioritize for conservation? Would they have a will to continue monitoring translocated species and allocate resources for these projects instead of spending money in other ways? Moreover, future generations are not a single unit but diverse communities with different and probably contradicting interests (see Abate 2019).

Notwithstanding, the necessity to prevent biodiversity from extinction from negative impacts of climatic factors in light of the principle of intergenerational equity does not impose obligations on the future generations to continue the conservation policy of the present generation. The future generations are equal to the present generation in their rights to establish their environmental policy even if that would mean diminishing the AM projects started before them. However, the principle of intergenerational equity does mean a commitment of the present generation to use 
every attempt in the prevention of biodiversity loss for a sake of the future generation including AM.

This view on the principle of intergenerational equity reflects an anthropogenic perspective. However, an understanding of this principle from the position of intrinsic value of species and their interests in the continuation of their existence is also a possible interpretation of this principle in favor of AM projects.

\subsection{The Principle of Progression}

The emerging principles of environmental law could also support AM projects and provide the necessary legal justification for them. As far as regulation on AM is a more anticipating law than the existing regulation, the principle of progression is directly relevant to AM issues.

While the principle of non-regression requires not to diminish the level of current legal protection, the principle of progression channels to a better law. The UN Secretary-General in his report on gaps in international environmental law singles out that the principle of non-regression is well-understood in human rights law and labor law, but it is a relatively new principle to the field of environmental law. However, the Paris Agreement is already explicit in its recognition of the idea of progression, i.e., improvement of a level of commitments of the Parties in their Nationally Determined Contributions (NDCs) (UN Secretary-General 2018, para 22; Paris Agreement Art 4 (3)). Both non-regression and progression (progressive realization) principles are not only incorporated in soft law instruments but also included in the novel treaties (see, e.g., Art 3 of the Regional Agreement on Access to Information, Public Participation and Justice in Environmental Matters in Latin America and the Caribbean (Escazú Agreement)).

According to Principle 13 of the IUCN Declaration, states, sub-national entities, and regional organizations must revise and enhance their law periodically considering the development of science and policy. Article 14 (1) of the Paris Agreement requires the Conference of the Parties (COP) serving as the meeting of the Parties (MOP) to the Agreement to assess periodically the collective progress towards the purpose and goals of the Agreement ("global stocktake"). The consideration of the best available science is an integral part of the assessment (Paris Agreement Art 14 (1)).

The idea of AM as human encroachment into natural processes for conservational purposes as such is an example of a progressive approach towards environmental policy. The commitments of states to periodically revise and enhance law on environmental protection considering the best available science and other factors provide the right guidance for the development of adaptive law and governance in general and law on AM.

\subsection{The Principle of Resilience}

Another emerging principle of environmental law is the principle of resilience. Resilience is an ability of a system to maintain its functions despite different external 
threats. Even though resilience can be negative, e.g., the resilience of poverty, in the context of environmental law, resilience is understood as a positive resilience of ecosystems and human communities (see Peraccini 2019, pp. 213-234).

At the international level, the 1972 Stockholm Conference, the 1992 Rio Conference, and the establishment of Sustainable Development Goals (SDGs) are among the milestones when new principles and ideas for the development of global environmental governance are added (Robinson 2020a, pp. 131-161). However, the situation with the existing environmental crises illustrates that the current endeavors are not enough and new principles are needed (ibid). Among them is the principle of resilience (ibid).

Robinson (2014) believes that resilience is an integral characteristic of humans and nature. However, the uncertainties and new threats posed by climate change require not to take resilience for granted but to gradually enhance capacity to "bounce back" (ibid). Regarding this, Robinson claims that the legal recognition of the principle of resilience would contribute to maintaining and enhancing resilience both in the social communities and in the ecosystems (ibid).

Both the IUCN Declaration and the Global Pact for the Environment contain obligations of states and other entities to maintain and restore the resilience of ecosystems and human communities (IUCN Declaration Principle 4; Global Pact for the Environment, Art16). SDG 13 is to take urgent actions to combat climate change and its impacts (UNGA 2015). Strengthening resilience and adaptive capacity in all countries is critical to achieving this goal (ibid 13.1).

AM combines varying conceptions, and it can have different purposes. Thus, species could be translocated to conserve endangered species, maintain production of commercial timber, or maintain ecosystem services. Within this spectrum, some AM projects are more dedicated to restoring or maintaining the resilience of ecosystems than others. McCormack even claims that climate change translocation law should be distinguished from endangered species protection law and focuses on translocation habitats and ecosystems for the protection of as many species as possible (McCormack 2018).

Against this backdrop, the principle of resilience does not favor different types of AM equally. It requires careful evaluation of the consequences and prioritizing those projects that contribute more to maintaining and enhancing resilience. However, even translocation of one species can be supported by the principle of resilience because of the contribution of such translocation to maintaining a diversity of species. Regarding this, the principle of resilience is among those principles of environmental law that support AM.

The above statements are true only to the extent that translocation does not have a significant adverse effect on recipient communities. The transformation of the ecosystems by anthropogenic activities is among the contributing factors to global pandemics and changes in disease dynamics (see Robinson 2020a, p. 136; 2020b, pp. 30-35). Supposedly, some diseases such as COVID-19, Avian influenza, Ebola, and HIV-1/AIDS could be kept within animals' communities (Robinson 2020b). However, the destructive impacts of human activities could turn viruses to search for new hosts, and thus, they have been transmitted to humans (ibid). These facts require maintenance of the existing ecosystems and their biological diversity, on the one 
hand, and careful evaluation of the risks related to translocations, on the other hand. Thus, the principles of environmental law including the principle of resilience are often of dual nature to AM. The next section will assess those of them which have strong normative provisions on minimizing the negative impacts of AM.

\section{Principles and Customary Norms that Would Minimize the Risks Associated with Assisted Migration}

As the previous section illustrates, the interpretation of customary norms and principles of international environmental law could lead to the conclusion that AM is necessary for saving species in the era of climate change. However, the specific regulation on AM should consider the risks of using this tool and a variety of factors involved. In constructing such regulation, customary norms and principles of international environmental law are also useful. Sometimes, they are the same principles and norms that encourage using AM. For example, an application of the precautionary principle does not only require not waiting for $100 \%$ scientific certainty on the risks of climatic changes for the species for conducting AM projects but also requires weighing the cost-effectiveness of such projects, their long-term, long-distant, and other consequences. This section will discuss how the precautionary principle, the principle of prevention and obligation to conduct environmental impact assessment, the principles of intergenerational equity, and ecological proportionality could guide the regulation of AM for minimizing its risks.

\subsection{The Precautionary Principle}

The previous section of the article acknowledges the precautionary principle as a justification of AM. However, this principle is also critical for dealing with the risks associated with the application of the tool.

Originally, when a dispute arises, a party that claims that activity is wrongful must prove her claim. However, the precautionary principle reverses the burden of proof. According to this reversed interpretation, an entity that intends to launch an activity must prove that it will not cause significant harm. This approach draws increasing attention (e.g., in the Pulp Mills case, see ICJ 2010).

It makes one consider the precautionary approach not only as encouragement to take actions in situations of scientific uncertainty but also as a restriction to actions when they could cause significant harm (The European Union (at the time of dispute the European Communities, EC) used this interpretation of the precautionary principle in the Beef Hormones case. See WTO Appellate Body 1998). The precaution towards actions whose consequences are uncertain is almost of the same level of significance as original encouragement to act to prevent possible harm (see Wiener 2018).

Applying this interpretation of the precautionary principle to the AM issues, one can figure it out that the principle does not only encourage to use of AM as a tool for biodiversity adaptation to climate change but also can restrict AM projects if they 
could potentially cause serious or irreversible harm, e.g., for the recipient ecosystems or public health.

The stakeholders must consider the indirect repercussions of AM seriously. Thus, Bradshaw (2019) points out that while the original purpose of translocation is to conserve species, the real consequences of such projects for species sometimes are no less than a loss of their original habitats and receiving lands of lower quality. She claims that even allocation of funding by one country for conservation of species at another country could finally mean reduction of efforts on the conservation of the original habitats (ibid). Bradshaw (2019) also believes that animal property rights concept can prevent expropriation of habitats from species). The entities involved in the AM projects should address these and other possible negative consequences of translocations thoroughly.

While the precautionary principle can both encourage and restrict AM, the additional tools are needed not to be in a situation of a regulatory deadlock and to find a way out. That could be assistance from other principles or additional conditions from the precautionary principle per se. Different versions of the precautionary principle consider possible impacts of the precautionary measures. Thus, the precautionary principle in the Rio Declaration requires cost-effectiveness of actions; Article 6 draft of the Global Pact for the Environment requires measures to be effective and proportionate (Le Club Des Juristes 2017).

Article 3 (3) of the UNFCCC requires the measures to be cost-effective and consider different socio-economic conditions of the participating countries. The cooperation of the parties of the UNFCCC is needed, and the measures should be comprehensive. These provisions are critical for the availability of the AM techniques both for developed and developing countries as well as for the consideration of possible transboundary impacts of translocations in decision-making.

A hazard (climate change impacts) and potential harm (extinction of species) are strongly connected with the issues of risks (likelihood of a negative situation to occur) and uncertainties (even if hazards and harm are clear, it still can be uncertain when and to what extent they can occur) (see Zander 2010, pp. 8-32). Such issues are critical for the development of regulation on AM. They are also related to the principle of prevention and the precautionary principle discussed in the article. Table 2 outlines the main issues related to risks and uncertainties in the regulation of AM (see also Karasov-Olson et al. 2021, p. 226).

Cost-benefit analysis can be an additional tool in decision-making concerning AM. However, its application is limited. The article argues that further development of cost-benefit analysis for assistance in making choices between AM and other instruments for biodiversity adaptation to climate change, for example, connectivity conservation, is promising. Nevertheless, cost-benefit analysis is less relevant to deciding whether to conduct measures on an adaptation of specific animals or plants to climate change as such or not. This is because of the difficulties in the monetization of species, risks of manipulation of the analysis, and inclusion of long-distance consequences in the analysis which affects discount rates. Further text will explain this in more detail.

Usually, environmental decision-making concerns two types of questions. First, the questions about the ends of environmental policy, the socially desirable level of 


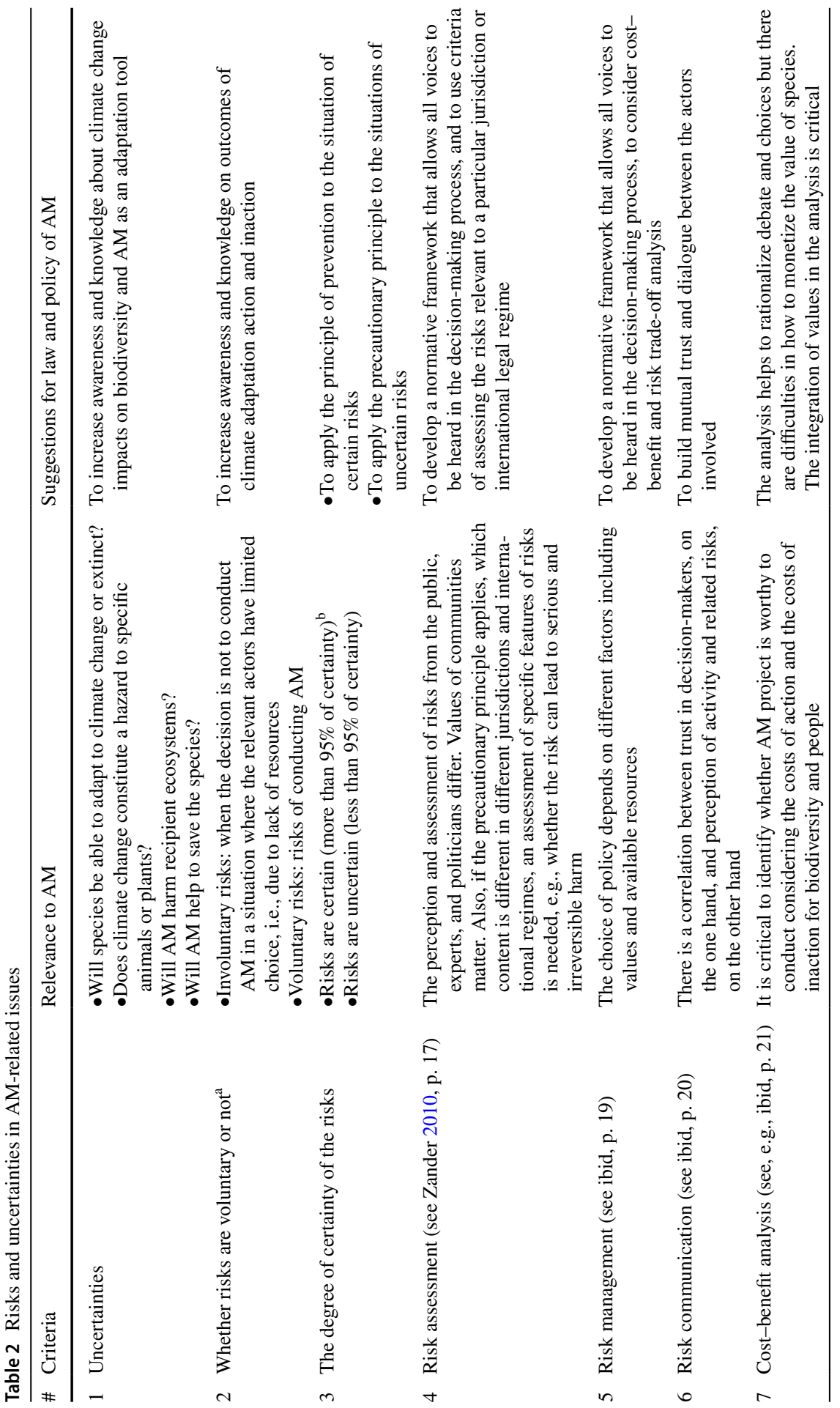




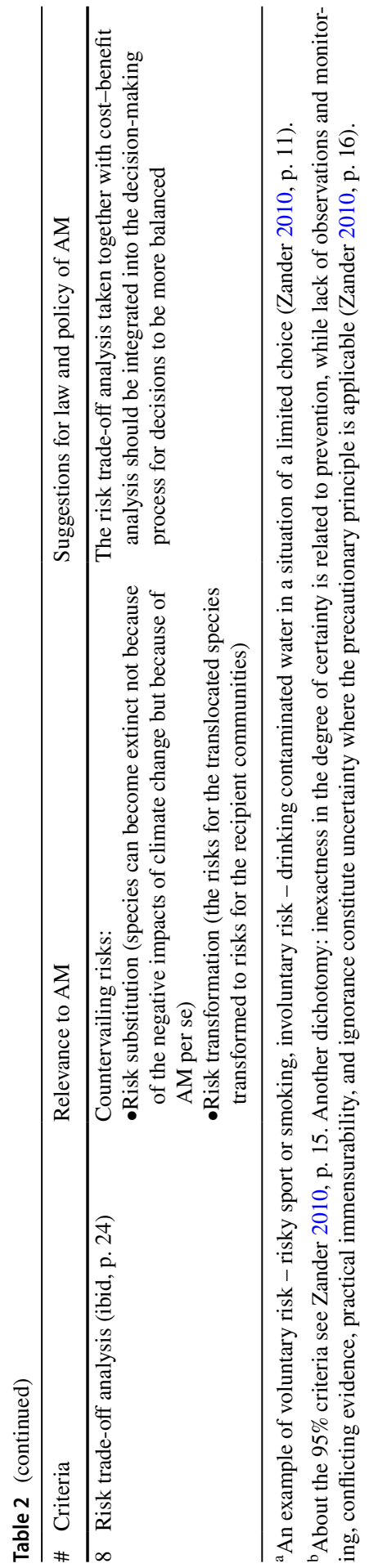


environmental quality (Livermore and Revesz 2017, p. 510). Second, the questions about the means of policymaking, types of regulatory instruments that will be used, and the allocation of responsibility between governmental actors (ibid). Concerning AM-related issues, the first group of questions is about whether to save specific species from the negative impacts of climate change or not, while the second group of questions concerns choices between AM and other instruments for biodiversity adaptation to climate change and practical implications of such choices. The latter group of questions seems relevant to AM. However, it is mainly should be done at local and national levels - at the closest level to a specific project. It is outside the scope of the article because it focuses on international cooperation. Regional and bilateral cooperation on AM with the assistance of cost-benefit analysis is theoretically possible, but it is untimely because at the current stage stronger integration of knowledge on climate change at those levels of cooperation is needed.

Further text will describe the basics of cost-benefit analysis and explain its limitations to deciding on whether to save species from climate change by using AM or not. The comparison of costs and benefits can be done by comparison of willingness to pay (WTP) for gains and willingness to accept (WTA) payment to bear costs (for losses) (Zerbe 2017, p. 358). The first difficulty in the application of these concepts to AM-related decision-making is difficulty in the monetization of losses of species because the value of having specific animals and plants alive could be of intrinsic, esthetic, cultural, and other reasons, rather than economic ones (see, e.g., Heise 2016).

What is possible is to calculate ecosystem services provided because of the existence of specific species and in case of loss of it. In this type of analysis, it is possible to compare WTP for AM with WTA in case of accepting the loss of species. However, at least at the current stage, the debate on AM mainly concerns saving specific species as such and not because of the necessity to maintain ecosystem services. Regarding this, the potential of cost-benefit analysis of AM concerning ecosystem services maintained by the existence of specific species is limited.

The second limitation of using AM is the possible manipulation of such analysis. AM is not a well-established instrument, and while cost-benefit analysis can contribute to the development of the concept, it also can be used in a manipulative manner by concerning stakeholders to achieve an outcome desirable for them (Zerbe refers to the Tellico Dam story and the George W. Bush Administration's Clear Skies initiative as examples (Zerbe 2017, p. 377)).

Third, AM mainly concerns the situations which can take place long after the decision-making. Thus, it relates to the problem of discount rate which is critical for cost-benefit analysis. For example, the present value of one million dollars at a two \% discount rate in 30 years will be around 0,5 million dollars and in 100 years slightly more than 13, 000 dollars (ibid, p. 360). At a seven \% discount rate, the value of one million dollars in 30 years will be around 130, 000 dollars and in 100 years slightly above 100 dollars (ibid, p. 360). Probably, the willingness to conduct AM can be predominated by a willingness to assist species to adapt to climate change regardless of economical savings for the next generations. Alternatively, the methodology of calculations and factors included in the analysis needs further development. 
The potential legal framework can contribute to the development of the use of the cost-benefit analysis in AM-related decision-making by identifying the factors which relevant for the analysis and the criteria which are critical for the economic calculation. Law can determine the base for deciding what is gain and what is a loss (ibid, p. 359).

The precautionary principle is incorporated in different law and policy documents at global, regional, and local levels. It requires to act to prevent harm even in situations when the knowledge is incomplete or inconclusive. This normative statement claims that stakeholders shall launch AM projects to prevent the extinction of species due to climatic stressors. However, the possible harm from AM also must be considered because the measures must be cost-effective and proportionate, and decision-makers shall address long-term, indirect, long-distance, and other consequences of their activities. Against this backdrop, among the further tasks in regulation on AM is a task to find the right balance between action and inaction because risk reduction activity could itself cause risk by paralyzing the regulation and development of environmental law (see Tomasovic 2018, pp. 93-150).

\subsection{The Principle of Prevention and Obligation to Conduct an Environmental Impact Assessment}

One of the main principles, which are relevant to the issues of controlling the risks of AM, is the principle of prevention. The principle of prevention is among the key principles of international environmental law (see Bodansky 2010, pp. 191-204; Sands et al. 2012, pp. 200-202; Duvic-Paoli 2018, pp. 161-173; Kravchenko et al. 2012, p. 43; De Sadeleer 2020, pp. 85-133). It requires states not to cause damage to the environment of other states or areas beyond national jurisdiction (UN Conference on the Human Environment 1972, Principle 21). This principle concerns two sides of AM. On the one hand, it relates to climate change challenge as such, i.e., prevention of GHGs emissions from the territories of states that taken together lead to the necessity of species to move. On the other hand, the principle of prevention concerns AM projects requiring identifying risks related to such projects and assessing them properly before the launch of the projects.

Principle 21 of the Stockholm Declaration combines the confirmation of sovereign rights of states to exploit their resources with states' responsibility to ensure that activities within their jurisdictions do not cause harm to the environment of other states and areas beyond the limits of national jurisdictions. The Rio Declaration reflects the same approach in Principle 2.

It is worth mentioning that sometimes the principle of prevention is distinguishable from provisions of Principle 21 of the Stockholm Declaration and Principle 2 of the Rio Declaration. Even though they are closely interconnected, the principle of prevention concerns not only transboundary issues but also obligations to prevent harm to the environment within a state's jurisdiction (see Sands et al. 2012, p. 201).

Currently, the principle of prevention is integrated with the due diligence obligation of states and the necessity to conduct environmental impact assessment in case of identification of a risk of the significant adverse impact of a project on 
the environment (the following decisions reflect this approach: Trail Smelter case (Tribunal 1938 and 1941); Legality of the Threat or Use of Nuclear Weapons (ICJ 1996); Gabčíkovo-Nagymaros Project (ICJ 1997); Pulp Mills on the River Uruguay (ICJ 2010); Certain Activities Carried Out by Nicaragua in the Border Area (Costa Rica v Nicaragua) and Construction of a Road in Costa Rica along the San Juan River (Nicaragua v Costa Rica) (ICJ 2015); see also Yotova 2016, pp. 445-448).

The Committee on Legal Principles Relating to Climate Change International Law Association (2014) included the principle of prevention in a list of principles related to climate change. However, the difficulties in the identification of humaninduced changes in the atmosphere as harm and other reasons lead to the debate on the applicability of the principle of prevention to climate change law (see Zahar 2014, pp. 217-233; Mayer 2015, pp. 1-24).

While mitigation of GHGs emissions is a necessary long-term strategy for biodiversity conservation, the necessity to help animals and plants to adapt to adverse impacts of climate change by AM is real even in the case of low mitigation scenarios. That is why the article does not engage in a broader debate on the relevance of the principle of prevention to climate change law and focuses directly on AM.

Scientists believe that AM projects could lead to a range of adverse impacts on the environment and public goods sometimes of the same level of significance as adverse impacts of climate change as such. This includes possible invasiveness of translocated organisms, other changes in recipient communities, and spread of diseases. Against this backdrop, does the principle of prevention require not to conduct AM projects at all?

One can find an answer in one of the first international disputes where the principle of prevention had been revealed - the Trail Smelter case between the USA and Canada. The dispute concerned the alleged harm from the Canadian Smelter at the US territory. The affirmation of the existence of harm and the establishment of a regime for the further operation of the Canadian plant were among the questions for the arbiters to answer. Even though they had established the existence of harm from the operation of the Smelter, they did not prescribe to cancel the operations. Instead, the award set the rules for further work of the factory (Tribunal 1938, 1941).

Moreover, in addition to the final award, arbitrators prescribed that the interpretation of the regime should not lead to the complete shut-down of the operations (ibid. Annex. I. Letter from the Members of the Tribunal to the Secretary of State of the United States and Secretary of State for External Affairs of Canada, May 6, 1941). Before this prescription, the Tribunal received a letter from technical consultants (ibid. Annex. II. Letter from the Technical Consultants to the Chairmen of the Trail Smelter Arbitral Tribunal, April 26, 1941). They have claimed that the strict interpretation of the regime would lead to the total cessation of the operations and that was not the original intention of the award (ibid).

Thus, the principle of prevention does not prescribe complete cessation of an activity that causes or may cause harm. Instead, it requires such activities to be manageable to the extent that satisfies the parties involved. In the case of AM, the threshold of possible harm to the recipient communities, or tolerable level of harm from translocations should be established (see, e.g., Lefeber 2015, pp. 92-102). 
The no-harm rule requires consideration of the admissibility of an activity. It can be done in three ways: (1) assessment of the admissibility of activity as such; (2) assessment of adverse effects of activity in the normal course of its operation; and (3) the risks of adverse environmental effects (ibid, p. 94). The application of this assessment model to AM-related issues requires clarification in international and domestic law: (1) whether the law prohibits AM or not (AM is prohibited if any introduction of novel species is prohibited); (2) if AM is allowed and the possibility of adverse effects is accepted, what kind of mechanisms can minimize such adverse effects; and (3) depending on the probability of risks implication of the precautionary principle or the principle of prevention is required.

As the Bramble Cay Melomys extinction case has shown, sometimes AM could be an urgent means, and its postponement could lead to an extinction of species (Woinarski and Burbidge 2016; Hance 2016; Purtill 2019). However, the urgency of the issues should not justify an absence of fulfillment of due diligence and environmental impact assessment (EIA) in the implementation of the principle of prevention. Thus, Costa Rica could not convince judges of the ICJ that an emergency because of the aggressive actions of Nicaragua was an appropriate reason for urgent construction of the road without fulfillment of procedural obligations of due diligence and EIA (ICJ 2015, para 158, 159. The court also has established that the construction of the road was under operation for several years before the conflict situation with Nicaragua).

Even if the principle of prevention in broader terms is relevant to AM issues, the applicability of due diligence and EIA to the AM projects requires further justification. The absence of the specific regulation on AM and lack of the appropriate amount of data on AM projects currently do not allow to conduct of such assessment properly. However, in the future, such evaluation can be the necessary next step in the development of law on AM. The integration of knowledge on climate change and its interlinkages with biodiversity protection is a necessary prerequisite for such evaluation. As of now, some preliminary observations on the applicability of EIA to AM can be outlined.

While AM aims to protect species from the negative impacts of climate change, AM itself can have negative impacts on the recipient ecosystems. EIA can help in preventing the negative impacts of AM. Even if EIA is not directly applicable to AM, it can be used as a model for the development of regulation on AM. The following text explains the limitations of EIA in the regulation on AM and outlines the main features of EIA that are relevant for further development of law on AM.

EIA assists decision-makers by providing information on the environmental outcomes of projects. However, the specific conditions when to conduct EIA, requirements to EIA, understanding of role and nature of EIA, and expectations from EIA vary from jurisdiction to jurisdiction (see, e.g., Fisher et al. 2019, pp. 693-742).

Usually, the law requires to conduct EIA when a project due to its size, nature, and location likely to have a significant effect on the environment (ibid, p. 693). Thus, in the EU, EIA is mandatory, for example, for crude-oil refineries, thermal power stations, and other combustion installations with a heat output of 300 megawatts or more, and installations for the reprocessing of irradiated nuclear fuel (The European Parliament and the Council 2011, Annex I). AM, at least as of now, is not 
that kind of a project. Moreover, EIA has its limitations, including limits of scientific knowledge (EIA is a form of prediction), a danger that too much faith is placed on it as a decision-making tool, and the fact that EIA does not dictate a particular outcome (Fisher et al. 2019, pp. 700-702). These features combined with uncertainties and the necessity for long-term modeling for AM make EIA to some extent irrelevant to AM projects.

However, a general mechanism of EIA can be a model for regulation on AM. Thus, the process of EIA usually includes screening (what activities should be subject to an assessment), scoping (local or global impacts), preparing an environmental impact statement, public participation, and making a decision (ibid, pp. 694-695). Additionally, the evolution of EIA enlarges its scope and includes the assessment of climate change impacts, which resonates with AM (see Peel 2015, pp. 348-358).

Another significant aspect in the implementation of the principle of prevention is the resolution of the conflict between parties involved in an appropriate and just way. Thus, the Trail Smelter Tribunal identified its role as "to endeavor to adjust the conflicting interests by some 'just solution' which would allow the continuance of the operation of the Trail Smelter but under such restrictions and limitations as would, as far as foreseeable, prevent damage in the United States" (Tribunal 1938 and 1941; see also ICJ 1997). Concerning AM, that would mean not to refrain from AM projects but to conduct them under such restrictions and limitations as would, as far as foreseeable, prevent damage to the ecosystems of other states.

In this context, it is critical not just to prevent a breach of substantive no harm obligations but to fulfill thoroughly procedural obligations. For example, in case of approval of their applicability to AM, the obligations of due diligence can be necessary and, if the risk of significant harm is foreseeable, to carry out an environmental impact assessment. Notification of neighboring states and other stakeholders and consultations with them are crucial (see ICJ 2010, 2015).

\subsection{The Principle of Intergenerational Equity}

The previous section of the article defines the principle of intergenerational equity as a justification of AM by the fact that the current generation must consider the needs of the future generations including their needs to enjoy the same level of biological diversity and the benefits related to it as the current generation does. However, the implementation of this principle is also critical for minimizing the risks associated with AM. It is about the risks to weaken the efforts to mitigate GHGs emissions in case of success of adaptation.

In the Urgenda case, The Supreme Court of the Netherlands (2019) rejected the position of the Dutch Government on adaptation. According to the Government, the lower courts had not considered adaptation measures of the authorities. The Supreme Court pointed out that adaptation measures are critical, but they should not be used as an excuse for postponing mitigation measures. Concerning an issue of $\mathrm{AM}$ in the context of intergenerational equity, such interpretation would mean that even a wide acceptance of AM as a tool of biodiversity adaptation to climate change should not be used as an excuse for diminishing or postponing mitigation efforts. 


\subsection{The Principle of Ecological Proportionality}

The emerging principles of environmental law are also critical for controlling the risks of AM. The IUCN Declaration enshrines principle in dubio pro natura (IUCN World Commission on Environmental Law 2016). This principle requires choosing an alternative that is less harmful to the environment. It also prohibits activities whose benefits are disproportionate in comparison with their negative impacts (ibid). This principle is closely related to the principle of substitution or ecological proportionality (see Winter 2018). The origin of the principle is in the norms on safety at work, e.g., on work with carcinogen substances (Council 1990). Later, the principle has been spread in environmental law and incorporated in legislation of some countries, e.g., in Germany (see Winter 2018).

The principle of ecological proportionality requires that activity with a potentially adverse effect on the environment should pursue a legitimate objective, be effective, necessary, and balanced (ibid). It is critical for the formulation of law on AM considering the possible risks of such projects for the recipient ecosystems. While the aim of AM project is legitimate (to help biodiversity adapt to climate change), its effectiveness, necessity, and balanced character must be proved for every single project based on the best available science and policy standards.

\section{Other Relevant Principles and Customary Norms}

The principles of cooperation, sustainable development including integration and intergenerational equity, common but differentiated responsibilities, and polluter pays principle provide necessary guidelines to channel activities from the necessity to conduct AM to its appropriate implementation.

The principle of cooperation is rooted in Article 74 of the UN Charter and then distilled in Principle 24 of the Stockholm Declaration and Principle 27 of the Rio Declaration. Article 74 of the UN Charter enshrines the principle of good neighborliness and requires states to consider the interests and well-being of the rest of the world. Article 74 does not articulate environmental issues as a matter of concern explicitly. It mentions only social, economic, and commercial blocks. However, the further interpretation of the treaty in light of the post-1945 development allows the inclusion of the environmental issues under the requirement to cooperate.

Principle 24 of the Stockholm Declaration reaffirms the cooperative spirit by all countries on equal footing in their affairs. The Declaration mentions multilateral, bilateral, and other means of cooperation with consideration of sovereignty and interests of all states. Principle 27 of the Rio Declaration enlarges the scope of the principle of cooperation including not only the cooperation of states but also people.

AM projects do need the cooperation of states and people considering the goals and possible risks related to this tool. The principle of cooperation requires considering priorities of other states and regions in the nature conservation and development which can be affected both by the implementation of AM and by rejecting of using this instrument. Proper implementation of the principle requires cooperating 
in good faith and a spirit of partnership from the very beginning of the planning AM projects.

The necessity to cooperate in these issues is strengthened by an understanding of the world's biodiversity and climate system as a common concern of humankind. The ICJ (1997) also held an approach based on an idea of cooperation in its decisions on the environment and natural resources.

In 1987, the Brundtland Report crystallized an idea of sustainable development as the necessity to meet the needs of the present generation without compromising the needs of the generations to come (World Commission on Environment and Development 1987, para 27). Since then, the principle of sustainable development pervades international environmental law in different ways. Usually, it is described by the necessity to integrate environmental protection into development projects and other human activities (the principle of integration; see Montini 2018, pp. 139-149), intergenerational (between current and future generations), and intragenerational (among already existing states, people, other species) equity (see Sands et al. 2012, pp. 206-217; Kravchenko et al. 2012, pp. 44-46).

Principle 13 of the Stockholm Declaration enshrines an integrated and coordinated approach to development planning. It is difficult to distinguish climate change as a single stressor that forces species to move and requires human intervention in a form of AM. Sometimes other factors, e.g., increasing competition with other species, contribute to the problem. Human development, urbanization, and habitat fragmentation cannot be separated from climatic factors. Thus, coastal squeeze (rising sea level, on the one hand, and the development of the coastal territory, on the other hand) can be a reason for implementing AM projects. Against this backdrop, the conservation of species in the era of climate change by using AM or any other tools should be integrated into the development planning.

Aside from the equity among generations, the equity within a generation is critical. In international environmental law, it concerns, first of all, equity in relationships between states. The modification of this idea is the principle of common but differentiated responsibilities.

The climate regime acknowledges that a response to climate challenge should be following the common but differentiated responsibilities of states and their respective capabilities and social and economic conditions (UNFCCC Preamble). Different conditions and development priorities of parties are also acknowledged by the legal regime under the CBD (Preamble).

The principle of common but differentiated responsibilities contains two main elements. The first is an idea of responsibility. States endorse that they sought solutions to the climate change challenge and biodiversity loss. In this context, the size of a state, its stage of development should not be used for diluting this general idea of responsibility.

However, eradication of poverty and other priorities can impose difficulties in fulfillment of the obligations of the states. That is why it is not possible to demand equal measures from different states.

The principle of common but differentiated responsibilities, taking together with the principles of cooperation and sustainable development, means that every state has a general obligation to preserve its biodiversity against the threats from 
climate change; however, the implementation of this obligation requires cooperation and assistance to developing countries from the developed ones.

The proper implementation of the principles described above requires the construction of a mechanism that allows biodiversity located in the territory of developing countries to enjoy the benefits of using AM instruments. That could be through the technologies transfer, funding, and support by experts from developed countries. However, the AM is a new instrument, and its proper assessment even in developed countries is needed. That is why, probably, the temporary unavailability of this tool for developing countries can be justified by the necessity to avoid unintended negative consequences from using this instrument.

Against this backdrop, should the developed countries as the main historic emitters of GHGs bear the costs of adaptation to climate change including AM projects in developing countries? One could try to find an answer in the polluter pays principle (see, e.g., Sands et al. 2012, pp. 228-232; Kravchenko et al. 2012, pp. 50-53; De Sadeleer 2020, pp. 31-81).

Even though the idea that a polluter should pay is well-established in environmental law, the total compensation of damage by a polluter is rare. Sometimes, the polluter shares the costs with victims of pollution (see, e.g., Convention on the Protection of the Rhine Against Pollution by Chlorides, Rhine Chloride Convention). Under the climate regime, the polluter pays principle is mainly reflected in the idea of the contribution of the main emitters in mitigation efforts than in sharing the burden of adaptation. That is why possible claims of developing countries for financing AM projects by developed countries based on the polluter pays principle are not well justified by existing law even though theoretically this argumentation does not sound irrelevant.

In addition to the general principles of international environmental law, customary norms can be relevant to AM issues, for example, customary norms on the responsibility to protect endangered species (see Glennon 1990, pp. 30-32). However, the difficulties in identification protection of what species forms the customary norms, how states identify the status of species as endangered, and other factors make the practical implementation of such norms highly problematic (ibid).

The existing principles of international environmental law shed some light on conducting AM projects. However, further evolution of law requires to enshrine more precise rules on the conduct of the states and inter-states communication concerning AM projects.

The following text will assess the relevance of the emerging principles of environmental law to AM. It states that even some of them are not directly relevant to AM as such they provide the necessary background for the development of law on AM. The principle of non-regression is one of those principles.

From first sight, the principle of non-regression sounds like a conservative statement on the development of environmental law (see Prieur 2018). However, it does not require stopping the evolution of environmental law. It reflects a reaction of academia on reduction of environmental protection and withdrawal of some states from environmental treaties (e.g., Canada from the Kyoto Protocol or the US from the Paris Agreement, see Prieur 2018). 
The IUCN (2016) included the principle of non-regression in its World Declaration on Environmental Rule of Law. In 2017, the draft Global Pact for the Environment also explicitly mentions non-regression among the principles of the Pact (Article 17). According to these documents, states, sub-national entities, and (in the IUCN Declaration) regional international organizations should refrain from diminishing the current level of environmental protection (IUCN Declaration, Principle 12; Global Pact for the Environment, Article 17).

The existing law and policy documents (with some exceptions such as the New South Wales's Translocation Operational Policy) do not contain comprehensive norms on AM. That is why the principle of non-regression cannot be interpreted as prevention from dismissing norms on AM.

However, what is significant is that in the creation and implementation of norms on AM states, sub-national entities and regional organizations should not follow the lower standards of evaluation of risks for translocating species and recipient communities than for other conservation instruments and development projects (i.e., in biodiversity offsets).

Non-regression also means that in terms of procedures AM should not be less inclusive or disclose less information than in other projects with similar possible consequences. Moreover, the maintaining of the level of protection provided by the existing law could reduce effectively other stressors such as habitat loss from development projects that in its turn would reduce the frequency of using AM from climatic stressors.

The development of the standards for assessment of proposals for AM, undertaking, and monitoring of such projects requires proper implementation of another emerging principle of environmental law-the principle of good governance (Kravchenko et al. 2012, pp. 58-60). This principle includes access rights-access to information, public participation, and access to justice in environmental matters.

Principle 10 of the Rio Declaration combines these three elements. The further development of the access rights follows the same pattern: access to environmental information, public participation, and access to justice in environmental matters are mentioned in combination (Global Pact for the Environment, Articles 9-11). It is worth mentioning that not only soft law documents but also regional multilateral environmental agreements incorporate access rights and develop their content (the Aarhus Convention and the Escazú Agreement).

The realization of procedural access rights is a prerequisite for the implementation of other principles and norms of environmental law. Thus, Peraccini (2019, pp. 213-234) in her concept of just resilience highlights public participation as a necessary element for building resilience. Public participation should not only include representatives of the entities that can articulate their existing interests but also represent the interests of future generations and nature (ibid). Camacho (2010) also singles out the critical role of procedural rights for adaptive governance in general and law on AM.

The further realization of an idea of AM in law indeed needs institutions that represent interests of translocating species and recipient communities considering not only the interests of the current generation of people, animals, and plants but also of future generations of human and biotic communities. Even with a lack of knowledge on what 
exact interests of future generations of people and biotic communities will be, the existence of representatives reflects a constructivist approach towards the future and facilitates objectivization of the interests of nature and future generations (see Abate 2019).

In this context, the concept of rights of nature and its implementation in law is critical for the further development of law on AM. This concept developed by Nash (1989) has been pursued in law and policy documents both at domestic and international levels. It is incorporated in the Constitution of Ecuador of 2008 (Title II, Chapter 7) and the legislation of Bolivia (Law of the Rights of Mother Earth of 7 December 2010, this law was revised as the Framework Law of Mother Earth and Integral Development for Living Well in 2012). The IUCN Declaration in its Principle 2 enshrines rights to nature (right to the conservation, protection, and restoration of ecosystems) and rights of nature (its inherent rights to exist, thrive, and evolve).

However, the fact that rights of nature take hold in law does not necessarily mean the promotion of AM, thus, Bolivian law obliges the state and society to ensure the necessary conditions for the living systems of Mother Earth to regenerate without significantly altering their structural and functional characteristics (Law of the Rights of Mother Earth Article 2 (3)). Article 73 of the Constitution of Ecuador requires the application of preventive and restrictive measures on activities that may lead to the extinction of species, the destruction of ecosystems, and the alteration of natural cycles. While AM aims to preserve species, it can lead to modification in recipient biotic communities. In this context, the recognition of rights of nature without further interpretation does not provide an explicit legal position in favor or against AM.

The emerging principles of international environmental law could contribute to the development of law on AM. While some of them, e.g., in dubio pro natura, are relevant to AM only taking together with other principles, others could lead to significant outcomes as such. Thus, the principle of non-regression requires using legal standards in the future law on evaluation of AM proposals and their implementation no less strict than standards for other projects. The principle of progression stimulates the development of law on AM considering the development of science and policy. The principle of resilience in general supports AM; however, it does not treat different types of AM, e.g., for conservation of species or maintaining ecosystem services, equally. The principle of ecological proportionality requires weighing up AM with other conservation tools and with the needs of development. The realization of access rights (access to information, public participation, and access to justice in environmental matters) does not only requires the development of norms towards a more inclusive and just representation of existing actors from human communities but also to consider interests of future generations of humans, translocating species, and recipient communities. It could be done through the further development of the concept of the rights of nature.

\section{Conclusion}

In the situation of lack of specific legal norms on AM, the role of customary norms and principles of international environmental law is difficult to exaggerate. They can guide the behavior of states, sub-national entities, international 
organizations, and people in the implementation of AM projects. They also channel the development of law on AM from its current level to the new forms.

The interpretation of some principles of environmental law encourages the use of AM. Thus, justification of using this instrument is rooted in the precautionary principle (the lack of scientific certainty on the future GHGs emissions and the response of biotic communities on them is not a reason for postponing translocation), an idea of intergenerational equity (the future generations have an interest in enjoying no less biodiversity than the current generation does), and the necessity to maintain and restore the resilience of human communities and ecosystems (more relevant to translocation of ecosystems and habitats but still relevant to translocation of a single species).

The future law on AM should have standards on evaluation of AM projects that are strict enough to identify and prevent harm from such projects (precautionary principle, principle of prevention, non-regression, principle of ecological proportionality). It should be inclusive enough and consider the interests of different stakeholders (principle of cooperation, principles of good governance including access to the environmental information, public participation, and access to justice in environmental matters). It should incorporate the possibility of AM into development plans and balance the need for the protection of the environment with the need to develop (principle of sustainable development, principle of common but differentiated responsibilities, and principle of integration).

The principles of progression, common but differentiated responsibilities, cooperation, intergenerational and intragenerational equity, and resilience require the development of the norms on just access of the world's biodiversity to AM as an instrument of adaptation of biodiversity to climate change. In this context, further development of the mechanisms of representation of future generations and nature is needed as well as the mechanisms of just transfer of technologies and financial support for AM between developed and developing countries considering their contribution to the climate change problem.

Acknowledgements I would like to thank my supervisors Distinguished Professor of the Research Institute of Environmental Law (RIEL) of Wuhan University, Emeritus Professor of Sydney Law School Ben Boer, Associate Professor of the RIEL of Wuhan University Liu Jing, Professor of the RIEL of Wuhan University, Professor of the China Institute of Boundary and Ocean Studies of Wuhan University Otto Spijkers as well as Professor of School of International Law at the Southwest University of Political Science and Law Alexander Zahar for their guidance and constant support. I am grateful to the Director of the RIEL of Wuhan University, Professor Qin Tianbao, and reviewers of the manuscript for their comments and suggestions. The research has received funding from the China Scholarship Council (CSC), CSC \# 2018GXZ016668 (PhD project).

\section{Declarations}

Competing Interests The author declares no competing interests.

Funding Chinese Government Scholarship,2018GXZ016668,Maksim Lavrik 


\section{References}

Abate RS (2019) Protection of future generations: prior to and during the Anthropocene era. In: Abate RS, Climate Change and the Voiceless: Protecting Future Generations, Wildlife, and Natural Resources. CUP, pp. 43-96. https://www.cambridge.org/core/services/aop-cambridge-core/conte nt/view/38EABEB7839D6410599E3028AB470ACE/9781108480116c3_43-96.pdf/protection_of_ future_generations.pdf. Accessed 13 April 2020

Backman K (2019) Protecting the cultural survival of the Sami: permanent sovereignty over natural resources and the role of free, prior and informed consent in the protection of the Sami right to culture. Åbo Akademi. https://www.doria.fi/bitstream/handle/10024/169434/backman_karin.pdf? sequence $=2$. Accessed 27 November 2021

Barral V, Dupuy P-M (2015) Principle 4: sustainable development through integration. In: Viñuales JE (ed), The Rio Declaration on Environment and Development: A Commentary. Oxford University Press, pp 157-180

Beyerlin U (2013, October) Sustainable development. In: Oxford Public International Law: Max Planck Encyclopedias of International Law. http://opil.ouplaw.com. Accessed 29 April 2021

Bodansky D (2010) The art and craft of international environmental law. Harvard University Press

Boer B (2015) Environmental principles and the right to a quality environment. In: Faure M (ed), Elgar Encyclopedia of Environmental Law. Edward Elgar Publishing, pp. 52-75

Boyle A (2009, March) Polluter pays. In: Oxford Public International Law: Max Planck Encyclopedias of International Law. http://opil.ouplaw.com. Accessed 29 April 2021

Bradshaw K (2019) Expropriating habitat. Harvard Environ Law Rev 43(1):77-118

Brodie JF, Lieberman S, Moehrenschlager A, Redford KH, Rodríguez JP, Schwartz M, Seddon PJ, Watson JEM (2021) Global policy for assisted colonization of species: coordinated policies are needed for the translocation of species for conservation. Sci 372(6541):456-458

Brown Weiss E (1992) In fairness to future generations and sustainable development. American University J Int Law and Policy 8(1):19-26

Brown Weiss E, Sornarajah A (2013, June) Good governance. In: Oxford Public International Law: Max Planck Encyclopedias of International Law. http://opil.ouplaw.com. Accessed 29 April 2021

Brunnée J (2010, March) Sic utere tuo ut alienum non laedas. In: Oxford Public International Law: Max Planck Encyclopedias of International Law. http://opil.ouplaw.com. Accessed 29 April 2021

Camacho AE (2010) Assisted migration: redefining nature and natural resources law under climate change. Yale J Regulation 27(2):171-256

Campanelli D (2011, March) Principle of solidarity. In: Oxford Public International Law: Max Planck Encyclopedias of International Law. http://opil.ouplaw.com. Accessed 29 April 2021

Cannone N, Pignatti S (2014) Ecological responses of plant species and communities to climate warming: upward shift or range filling processes?'. Clim Change 123(2):201-214. https://doi.org/10. 1007/s10584-014-1065-8

Committee on Legal Principles Relating to Climate Change, International Law Association (2014, April 7-11) Resolution 2/2014. Declaration on legal principles relating to climate change. Washington

Conference of Judges and Prosecutors (2018, March 21) Brasília declaration of judges on water justice [10 Principle Declaration]. $8^{\text {th }}$ World Water Forum Brasília (Brazil). https://www.iucn.org/sites/ dev/files/content/documents/brasilia_declaration_of_judges_on_water_justice_21_march_2018_ final_as_approved_0.pdf. Accessed 11 May 2021

Cooney R, Dickson B (eds) (2012) Biodiversity and the precautionary principle: Risk and uncertainty in conservation and sustainable use. Earthscan from Routledge

Council (1990, June 28) Directive 90/394/EEC on the protection of workers from the risks related to exposure to carcinogens at work. OJ L 196, 26 July 1990, 1-7 (no longer in force)

The Supreme Court of Pakistan (Appellate Jurisdiction) (2021, February 11) CP 1290-L/2019 DG Khan Cement Company Ltd v Government of Punjab through its Chief Secretary, Lahore. Judgment

The European Parliament and the Council (2011, December 13) Directive 2011/92/EU on the assessment of the effects of certain public and private projects on the environment (codification) OJ L 026, 28.01.2012, 1

Duvic-Paoli L-A (2018) Principle of prevention. In: Krämer L, Orlando E. (eds), Principles of environmental law. Edward Elgar Publishing, pp. 161-173

Emas R (2015) Brief for GSDR: The concept of sustainable development: definition and defining principles. https://asset-pdf.scinapse.io/prod/2184349672/2184349672.pdf. Accessed 27 November 2021 
Epiney A (2009, January) Environmental impact assessment. In: Oxford Public International Law: Max Planck Encyclopedias of International Law. http://opil.ouplaw.com. Accessed 29 April 2021

Fisher E, Lange B, Scotford E (2019) Environmental law: text, cases, and materials, 2nd edn. OUP

The International Court of Justice (1997, September 25) Gabčíkovo-Nagymaros project (Hungary v Slovakia) Judgement. ICJ Rep 7

Glasson J, Therivel R, Chadwick A (2012) Introduction to environmental impact assessment, 4th edn. Routledge

Glennon MJ (1990) Has international law failed the elephant. American J Int Law 84(1):1-43

Le Club Des Juristes (2017, June 24) Global pact for the environment. Draft Project. La Sorbonne, Paris. https://www.iucn.org/sites/dev/files/content/documents/draft-project-of-the-global-pact-for-theenvironment.pdf. Accessed 18 March 2020

Hagerman S, Kozak R (2021) Disentangling the social complexities of assisted migration through deliberative methods. J Ecol 109(6):2309-2316. https://doi.org/10.1111/1365-2745.13667

Hällfors MH, Aikio S, Schulman LE (2017) Quantifying the need and potential of assisted migration. Biol Cons 205:34-41. https://doi.org/10.1016/j.biocon.2016.11.023

Hällfors M, Vaara EM, Ahteensuu M, Kokko K, Oksanen M, Schulman LE (2018) Assisted migration as a conservation approach under climate change. Reference Module in Earth Systems and Environmental Sciences. Encycl Anthropocene 2:301-305

Hällfors M, Vaara EM, Hyvärinen M, Oksanen M, Schulman LE, Siipi H, Lehvävirta S (2014) Coming to terms with the concept of moving species threatened by climate change - a systematic review of the terminology and definitions PLOS ONE 9 (7). https://doi.org/10.1371/journal.pone.0102979

Hance J (2016, June 29) 'Devastated': scientists too late to captive breed mammal lost to climate change. The Guardian. https:/www.theguardian.com/environment/radical-conservation/2016/jun/29/bramb le-cay-melomys-australia-extinction-climate-change-great-barrier-reef. Accessed 08 June 2020

Heise UK (2016) Imagining extinction: the cultural meanings of endangered species. The University of Chicago Press

Hey E (2011, February). Common but differentiated responsibilities. In: Oxford Public International Law: Max Planck Encyclopedias of International Law. http://opil.ouplaw.com. Accessed 29 April 2021

Honkonen T (2015) The development of the principle of common but differentiated responsibilities and its place in international environmental regimes. In: Kuokkanen T, Couzens E, Honkonen T, Lewis M (eds) International Environmental Law-making and Diplomacy; Insights and Overviews, 1st edn. Routledge, London, p 24

IUCN World Commission on Environmental Law (2016, April 26-29) IUCN World Declaration on the Environmental Rule of Law. https://www.iucn.org/sites/dev/files/content/documents/english_ world_declaration_on_the_environmental_rule_of_law_final.pdf. Accessed 17 April 2020 (IUCN Declaration)

Janusz-Pawletta B, Gubaidullina M (2015) Transboundary water management in central Asia: legal framework to strengthen interstate cooperation and increase regional security. Cahiers D'asie Centrale 25:195-215

Kabaz-Gomez J (2012) Rules for playing God: the need for assisted migration \& new regulation. Animal Law 19(1):111-150

Karasov-Olson A, Schwartz MW, Olden JD, Skikne S, Hellmann JJ, Allen S, Brigham C, Buttke D, Lawrence DJ, Miller-Rushing AJ, Morisette JT, Schuurman GW, Trammell M, Hoffman CH (2021) Ecological risk assessment of managed relocation as a climate change adaptation strategy. U.S. National Park Service Publications and Papers. https://digitalcommons.unl.edu/natlpark/226. Accessed 28 April 2021

Koester V (2015) Environmental principles and concepts in biodiversity treaties. In: Faure M (ed), Elgar Encyclopedia of Environmental Law. Edward Elgar Publishing, pp. 538-554

Koivurova T (2010, February) Due diligence. In: Oxford Public International Law: Max Planck Encyclopedias of International Law. http://opil.ouplaw.com. Accessed 29 April 2021

Kotzur M (2009, January) Good faith (bona fide). In: Oxford Public International Law: Max Planck Encyclopedias of International Law. http://opil.ouplaw.com. Accessed 29 April 2021

Kravchenko S, Chowdhury TMR, Bhuiyan MdJH (2012) Principles of international environmental law. In: Alam S, Bhuiyan MdJH, Chowdhury TMR, Techera EJ (eds), Routledge Handbook of International Environmental Law. Routledge

Kulesza J (2016) Due diligence in international law. Brill, Nijhoff, Leiden/Boston

Lefeber R (2015) Responsibility not to cause transboundary environmental harm. In: Faure M (ed), Elgar Encyclopedia of Environmental Law. Edward Elgar Publishing, pp. 92-102 
Livermore MA, Revesz RL (2017) Environmental law and economics. In: Parisi F (ed), The Oxford Handbook of Law and Economics. Volume 2: Private and Commercial Law. OUP

Lopez J (2015) Biodiversity on the Brink: the role of assisted migration in managing endangered species threatened with rising seas. Harvard Environ Law Review 39(1):157-190

Malaihollo M (2021) Due diligence in international environmental law and international human rights law: a comparative legal study of the nationally determined contributions under the Paris agreement and positive obligations under the European convention on human rights. Netherlands Int Law Review 68:121-155. https://doi.org/10.1007/s40802-021-00188-5

Mancilla A (2016) Shared sovereignty over migratory natural resources. Res Publica 22:21-35. https:// doi.org/10.1007/s11158-015-9309-7

Mayer B (2015) The applicability of the principle of prevention to climate change: a response to Zahar. Climate Law 5(1):1-24

McCormack PC (2018) Conservation introductions for biodiversity adaptation under climate change. Transnational Environ Law 7(2):323-346

McIntyre O (2020) The current state of development of the no significant harm principle: how far have we come? Int Environ Agreements: Politics, Law and Economics 20:601-618. https://doi.org/10. $1007 /$ s10784-020-09501-8

Michallet I (2018) Equity and the interests of future generations. In: Krämer L, Orlando E (eds), Principles of Environmental Law. Edward Elgar Publishing, pp. 150-160

Milligan B, Macrory R (2015) The history and evolution of legal principles concerning the environment. In: Faure M (ed), Elgar Encyclopedia of Environmental Law. Edward Elgar Publishing, pp. 23-37

Montini M (2018) The principle of integration. In: Krämer L, Orlando E (eds), Principles of Environmental Law. Edward Elgar Publishing, pp. 139-149

Morgera E (2015) The ecosystem approach and the precautionary principle. In: Faure M (ed), Elgar Encyclopedia of Environmental Law. Edward Elgar Publishing, pp. 70-80

Munir M (2013) History and evolution of the polluter pays principle: how an economic idea became a legal principle? https://doi.org/10.2139/ssrn.2322485

Nash RF (1989) The rights of nature: a history of environmental ethics. The University of Wisconsin Press

O'Riordan T, Cameron J (2013) Interpreting the precautionary principle. Routledge, London. https://doi. org/10.4324/9781315070490

Office of Environment and Heritage (NSW Government) (2019, first published 7 May, reprinted 20 May) Translocation operational policy. https://www.environment.nsw.gov.au/-/media/OEH/CorporateSite/Documents/Animals-and-plants/Threatened-species/translocation-operational-policy-190162. pdf. Accessed 24 February 2020

World Commission on Environment and Development (1987) Our common future. OUP https://susta inabledevelopment.un.org/content/documents/5987our-common-future.pdf. Accessed 10 April 2020 (Brundtland Report)

Park A, Talbot C (2018) Information underload: ecological complexity, incomplete knowledge, and data deficits create challenges for the assisted migration of forest trees. Bioscience 68(4):251-163. https://doi.org/10.1093/biosci/biy001

Peel J (2015) Environmental impact assessments and climate change. In: Faure M (ed), Elgar Encyclopedia of Environmental Law. Edward Elgar Publishing, pp. 348-358

Peeters M (2015) Environmental principles in international climate change law. In: Faure M (ed), Elgar Encyclopedia of Environmental Law. Edward Elgar Publishing, pp. 509-524

Peraccini M (2019) Towards Just resilience: representing and including new constituencies in adaptive governance and law. J Environ Law 31(2):213-234. https://doi.org/10.1093/jel/eqz002

Peterson St-Laurent G, Hagerman S, Kozak R (2018) What risks matter? Public views about assisted migration and other climate-adaptive reforestation strategies. Clim Change 151:573-587. https:// doi.org/10.1007/s10584-018-2310-3

Prieur M (2018) The principle of non-regression. In: Krämer L, Orlando E (eds), Principles of Environmental Law. Edward Elgar Publishing, pp. 251-259

Purtill J (2019, February 20) An Australian rodent has become the first climate change mammal extinction. Triple J Hack. Australian Broadcasting Corporation. https:/www.abc.net.au/triplej/programs/ hack/bramble-cay-melomys-first-climate-change-mammal-extinction/10830080. Accessed 08 June 2020

UN Conference on Environment and Development (1992, June 3-14) Rio Declaration on Environment and Development. ILM 31:874 (Rio Declaration) 
Robinson NA (2014) The resilience principle. IUCN Acad Envtl L eJournal 5:19. https://digitalcommons. pace.edu/lawfaculty/953/. Accessed 27 August 2020

Robinson NA (2020a) Ecological civilization and legal norms for resilient governance. Chinese J Environ Law 4:131-161

Robinson NA (2020b, November/December) The next pandemic is here. The Environmental Forum, pp.30-35

De Sadeleer N (2014) Polluter pays principle. In: Morin J-F, Orsini A (eds), Essential concepts of global environmental governance, 1st edn. Routledge, London, pp. 155-156. https://doi.org/10.4324/ 9780203553565

De Sadeleer N (2020) Environmental law principles: from political slogans to legal rules, 2nd edn. OUP, pp. 135-361

Sands P, Peel J, Fabra A, MacKenzie R (2012) Principles of international environmental law, 3rd edn. Cambridge University Press

Sang Z, Hamann A, Aitken SN (2021) Assisted migration poleward rather than upward in elevation minimizes frost risks in plantations. Clim Risk Manag 34:100380. https://doi.org/10.1016/j.crm.2021. 100380

Schrijver NJ (2008, June) Permanent sovereignty over natural resources. In: Oxford Public International Law: Max Planck Encyclopedias of International Law. http://opil.ouplaw.com. Accessed 29 April 2021

Schröder M (2014, March) Precautionary approach / principle. In: Oxford Public International Law: Max Planck Encyclopedias of International Law. http://opil.ouplaw.com. Accessed 29 April 2021

UN Secretary-General (2018, November 30) Gaps in international environmental law and environmentrelated instruments: towards a global pact for the environment (report) A/73/419*

Sinaga (2013) The non-compliance with the principle of cooperation and the political implication: a pragmatic review. Asian Soc Sci 9(12):156-161. https://doi.org/10.5539/ass.v9n12p156

Steel D (2015) Philosophy and the precautionary principle: science, evidence, and environmental policy. Cambridge University Press

Tanzi AM (2020) The inter-relationship between no harm, equitable and reasonable utilisation and cooperation under international water law. Int Environ Agreements: Politics, Law and Economics 20:619-629. https://doi.org/10.1007/s10784-020-09502-7

The International Court of Justice (1996, July 8) Legality of the threat or use of nuclear weapons. Advisory Opinion. ICJ Rep 226

The International Court of Justice (2010, April 10) Pulp mills on the River Uruguay (Argentina v Uruguay), Judgement. ICJ Rep 14

The International Court of Justice (2015, December 16) Certain activities carried out by nicaragua in the border area (Costa Rica v Nicaragua) and construction of a road in Costa Rica along the San Juan River (Nicaragua v Costa Rica). Judgment. ICJ Rep 665

The Supreme Court of the Netherlands (2019, December 20) The state of the Netherlands (Ministry of Economic Affairs and Climate Policy) v Stichting Urgenda, Judgement. ECLI:NL:HR:2019:2007. https://www.urgenda.nl/wp-content/uploads/ENG-Dutch-Supreme-Court-Urgenda-v-Netherlands20-12-2019.pdf. Accessed 10 April 2020 (Urgenda case)

Tomasovic B (2018) Tradeoffs in environmental law. Journal of Land Use \& Environmental Law 34:121

Tribunal (1938, April 16 and 1941, March 11) Trail Smelter case (United States v Canada): awards. Reports of International Arbitral Awards (2006)III: 1905-1982

UN Conference on the Human Environment (1972, June 5-16) Declaration of the United Nations Conference on the Human Environment. http://www.un-documents.net/unchedec.htm. Accessed 06 April 2020 (Stockholm Declaration)

UNEP, UNEP Training Manual on International Environmental Law. https:/www.unep.org/resources/ report/unep-training-manual-international-environmental-law. Accessed 25 February 2021

UNGA (2015, September 25) Res 70/1 transforming our world: the 2030 agenda for sustainable development. A/Res/70/1

Vanderheiden, S (2014) Common but differentiated responsibility. In: Morin J-F, Orsini A (eds), Essential Concepts of Global Environmental Governance, 1st edn, Routledge, London, p. 3 https://doi. org/10.4324/9780203553565

Wiener JB (2018) Precautionary principle. In Krämer L, Orlando E (eds), Principles of Environmental Law. Edward Elgar Publishing, pp. 174-185

Winter G (2018) Substitution: from alternatives to ecological proportionality. In: Krämer L, Orlando E (eds), Principles of Environmental Law. Edward Elgar Publishing, pp. 234-250 
Woinarski J, Burbidge AA (2016) Melomys rubicola. The IUCN Red List of Threatened Species 2016: e.T13132A97448475. https://doi.org/10.2305/IUCN.UK.2016-2.RLTS.T13132A97448475.en

Wolfrum R (2009, November) Common heritage of mankind In: Oxford Public International Law: Max Planck Encyclopedias of International Law. http://opil.ouplaw.com. Accessed 29 April 2021

Wolfrum R (2010, April) International law of cooperation In: Oxford Public International Law: Max Planck Encyclopedias of International Law. http://opil.ouplaw.com. Accessed 29 April 2021

Wolfrum R (2011, May) Sources of international law. In: Oxford Public International Law: Max Planck Encyclopedias of International Law. http://opil.ouplaw.com. Accessed 28 April 2021

Wood C (2013) Environmental impact assessment: a comparative review. 2nd edn. Routledge, London. https://doi.org/10.4324/9781315838953

WTO Appellate Body (1998, January 16) EC measures concerning meat and meat products (hormones): Report. AB-1997-4, WT/DS26/AB/R, WT/DS48/AB/R

Yotova R (2016) The principles of due diligence and prevention in international environmental law. Cambridge Law J 75(3):445-448

Zahar A (2014) Mediated versus cumulative environmental damage and the international law association's legal principles on climate change. Climate Law 4(3-4):217-233

Zander J (2010) The application of the precautionary principle in practice: comparative dimensions. CUP

Zerbe RO (2017) Cost-benefit analysis in legal decision-making. In: Parisi F (ed), The Oxford Handbook of Law and Economics. Volume 1: Methodology and Concepts. OUP

Publisher's Note Springer Nature remains neutral with regard to jurisdictional claims in published maps and institutional affiliations. 